\title{
REVIEW
}

\section{Linkage between crustacean zooplankton and aquatic bacteria}

\author{
Kam W. Tang ${ }^{1}$, Valentina Turk ${ }^{2}$, Hans-Peter Grossart ${ }^{3, *}$ \\ ${ }^{1}$ Virginia Institute of Marine Science, College of William \& Mary, Gloucester Point, Virginia 23062, USA \\ ${ }^{2}$ National Institute of Biology, Marine Biology Station, 6330 Piran, Slovenia \\ ${ }^{3}$ Leibniz-Institute of Freshwater Ecology and Inland Fisheries, Dept. Limnology of Stratified Lakes, Alte Fischerhuette 2, \\ 16775 Stechlin, Germany
}

\begin{abstract}
Bacteria and metazoan zooplankton (mainly crustaceans) are often viewed as 2 separate functional groups in the pelagic food webs indirectly linked via nutrient cycling and trophic cascades. Yet a zooplankter's body carries a high abundance of diverse bacteria, often at an equivalent concentration orders of magnitude higher than the ambient bacterial concentration. Zooplankton bodies are organic-rich micro-environments that support fast bacterial growth. Their physical-chemical conditions differ from those in the surrounding water and therefore select for different bacterial communities, including anaerobic bacteria that otherwise may not thrive in a well-oxygenated water column. The zooplankton body provides protection to the associated bacteria from environmental stresses similar to biofilms. Furthermore, migration by zooplankton enables rapid dispersal of bacteria over vast distances and across boundaries such as the pycnocline. In addition to live zooplankton, molts, fecal pellets, and carcasses of zooplankton all influence water column and benthic microbial communities in various ways. We review the recent advances in the study of (crustacean) zooplankton-bacteria interactions and discuss future research opportunities and challenges. Traditional aquatic microbial ecology emphasizes free-living bacteria, which represent only a fraction of the microbial world. By transcending disciplinary boundaries, microbial ecologists and zooplankton ecologists can work together to integrate the two disciplines and advance our understanding in aquatic microbial ecology.
\end{abstract}

KEY WORDS: Zooplankton · Bacteria $\cdot$ Zooplankton-bacteria interactions $\cdot$ Food web $\cdot$ Bacterial dispersal $\cdot$ Hotspots

Resale or republication not permitted without written consent of the publisher

\section{INTRODUCTION}

Bacteria and metazoan zooplankton are important components of the pelagic food web and major contributors to pelagic biodiversity and biogeochemical processes. Although both inhabit the same environment, they are often treated as separate functional units only indirectly connected via nutrient cycling and trophic cascades (Azam \& Malfatti 2007). The seeming lack of physical structures in the water column gives the impression that pelagic bacteria are living in a rather homogeneous environment, and respond only to pre- dation, viral attack, and physical-chemical changes in the surrounding water. This 'free-living bacteria' point of view still dominates the primary literature and text books, and microbial ecologists often ignore zooplankton and other higher organisms as potential habitats for aquatic bacteria except for a few pathogenic species. Likewise, zooplankton ecologists tend to focus only on interactions between zooplankton and their prey or predators, and because bacteria do not usually fall within either category, they are often overlooked by zooplankton ecologists. Consequently, microbial ecology and zooplankton ecology are taught and prac- 
ticed as separate disciplines, and collaboration between the two is very limited.

In reality, however, bacteria and zooplankton can be closely linked in occurrence and ecological functions (Fig. 1). For example, the exoskeleton and gut lining of a copepod provide favorable surfaces for bacterial attachment (Nagasawa \& Nemoto 1988, Pruzzo et al. 1996, Carman \& Dobbs 1997; Fig. 2). Bacterial attachment is not limited to crustacean zooplankton, and symbiotic bacteria have been observed in non-crustacean zooplankton such as appendicularians (Flood 1991), rotifers (Selmi 2001), and jellyfish (Schuett \& Doepke 2009). However, the biological characteristics of many of these bacteria remain obscure.

Readers who are familiar with current aggregate research will realize the importance of bacterial attachment and surface colonization in aquatic microbial ecology (Simon et al. 2002, Carrias \& SimeNgando 2009). There is growing evidence that bacterial attachment to aggregates and phytoplankton has profound effects on nutrient cycling and microbial evolution (reviewed by Grossart 2010). However, there is a very important difference between aggregates and zooplankton: A detrital aggregate is composed of pri- marily non-living particles, and it cannot regenerate itself or actively interact with bacteria. In contrast, a live zooplankter actively and continuously interacts with the bacteria that inhabit its body, leading to a dynamic and complex relationship between them. The few existing quantitative studies have shown that the equivalent bacterial concentrations associated with zooplankton, i.e. bacterial abundance per unit of zooplankton body volume, range between $10^{7}$ and $10^{11}$ $\mathrm{ml}^{-1}$ (Table 1), which are orders of magnitude higher than that in the surrounding water. Zooplankton-associated bacteria include those that attach to the exterior and interior of zooplankton bodies (e.g. symbionts) and those that are temporarily present in the gut (ingested bacteria). Even at a population density of just 1 zooplankter $\mathrm{l}^{-1}$, the abundance of these zooplankton-associated bacteria could rival that of free-living bacteria. Because of the heterogeneous distribution of zooplankton (Folt \& Burns 1999), bacterial processes associated with zooplankton occur in spatial and temporal scales that cannot be properly characterized by conventional sampling techniques. Hence, what we have learned from traditional microbial ecological studies represents only the tip of an iceberg, and it is unset-

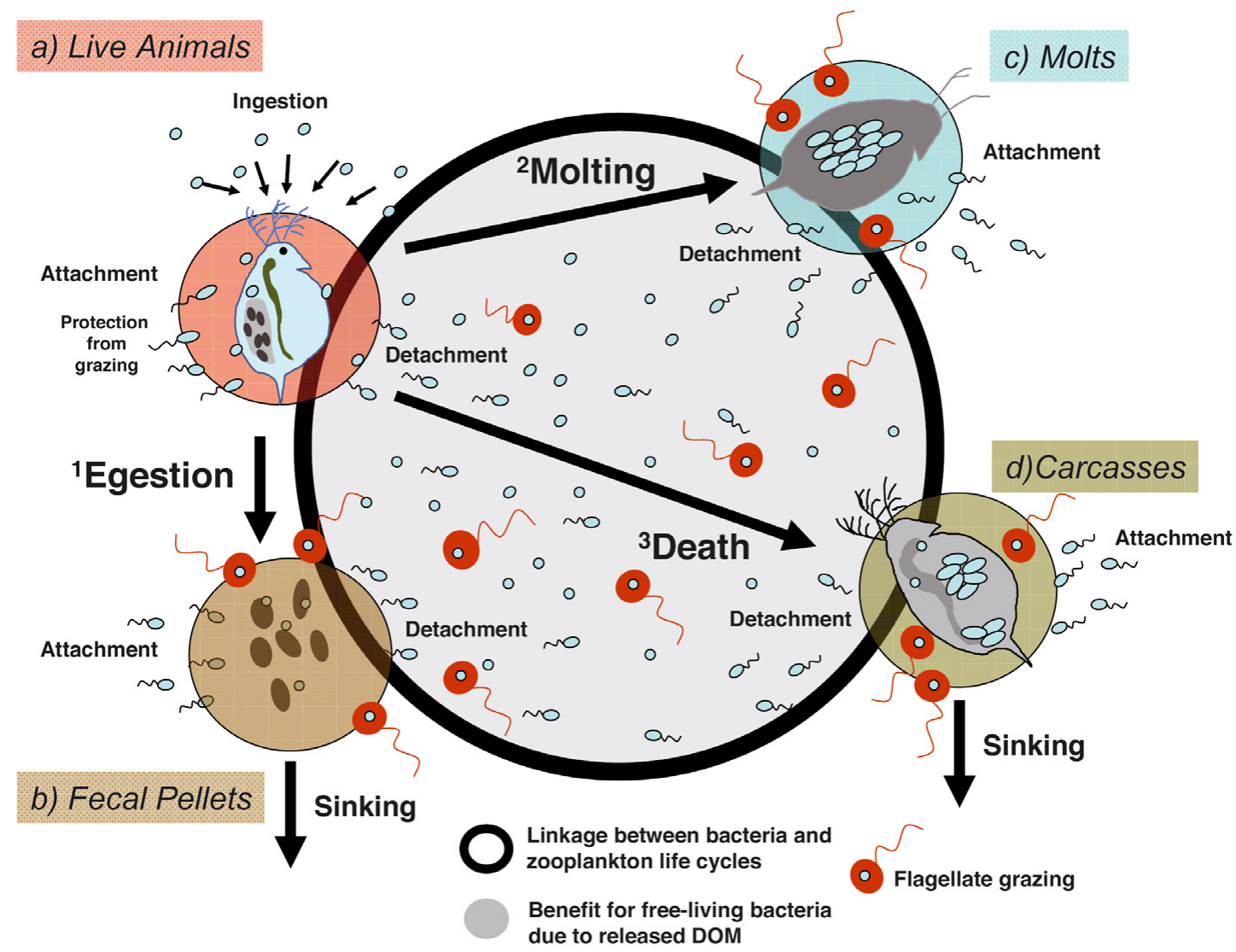

Fig. 1. Conceptual view of linkages between life cycles of zooplankton and aquatic bacteria. (a-d) Different types of zooplanktonderived organic matter which is subjected to bacterial colonization and degradation. Superscripts 1, 2, and 3 indicate the major processes by which zooplankton generate different types of organic matter. DOM: dissolved organic matter 

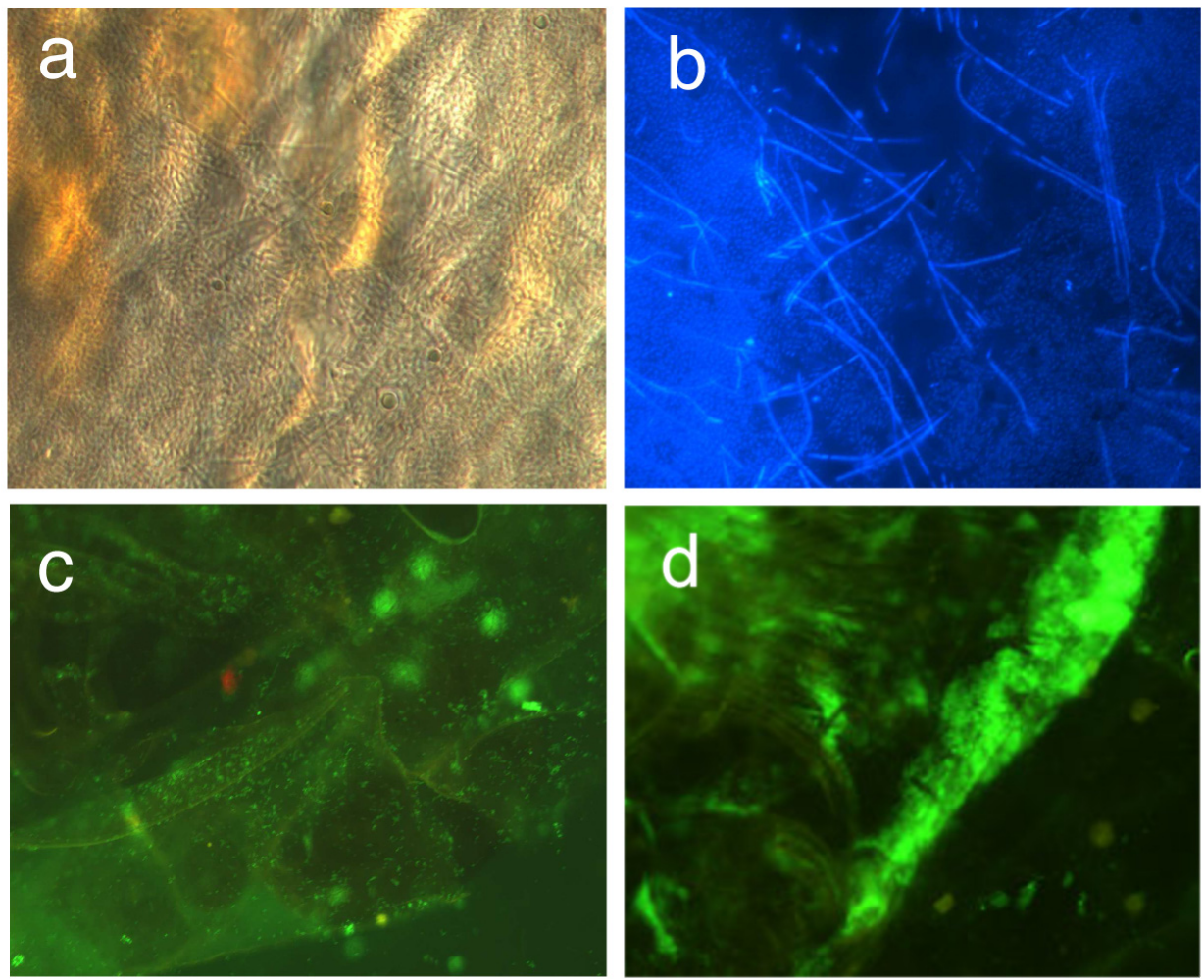

Fig. 2. Bacteria attached to a zooplankton body surface can be directly observed by (a) phase contrast microscopy and (b) 4',6-diamidino-2-phenylindole (DAPI) epifluorescence microscopy. Labeling the bacteria with green fluorescent protein (GFP) also allows researchers to directly observe (c) attachment of live bacteria to the zooplankton body surface and (d) their presence inside the zooplankton gut

tling to realize how much of the aquatic microbial world remains unexplored by scientists when neglecting bacteria associated with zooplankton and other organisms.

Although earlier review papers on the subject do exist (e.g. Harris 1993, Carman \& Dobbs 1997), they are largely limited to describing abundances and species compositions. Because earlier studies on zooplankton-associated bacteria relied on culturing techniques or biochemical assays, they likely have missed many of the bacterial phylotypes. Modern molecular techniques, in comparison, allow for phylogenetic investigation of these bacterial communities in greater detail, and experimental studies conducted in recent years have also shed light on the complex relationship between zooplankton and their associating bacteria. A more up-to-date review of the subject is therefore warranted.

In this review, we do not deal at length with pathogenic bacteria such as Vibrio species, for which a tight association with various zooplankton species has been discussed in detail by others (e.g. Huq et al. 1983, Cottingham et al. 2003). We also do not focus on the more obvious types of zooplankton-bacteria interactions such as predation, trophic cascades, or nutrient recy- cling (including sloppy feeding), which have been extensively addressed in the literature. Instead, we focus on zooplankton as an important and unique microhabitat for many pelagic bacteria and the interactions between the two, and point to future challenges and opportunities in this research field. Much of the work described in this article is limited to crustacean zooplankton in coastal and estuarine environments and to a lesser extent limnetic systems, whereas comparable research on gelatinous zooplankton and microzooplankton in the open ocean environment remains scarce. Considering the ubiquity and large abundances of zooplankton in marine and freshwater environments, tight associations between zooplankton and bacteria can widely affect bacterial behavior, growth, and biogeochemical activities (Dattagupta et al. 2009). In times of rapid global change, there is an urgent need for advancing our understanding of zooplankton-bacteria interactions and how they would respond to future climate scenarios, a goal that can be achieved when scientists from both fields transcend conventional thinking and disciplinary boundaries, and begin to work together on the subject. It is our hope that this article serves as a catalyst for such collaboration. 
Table 1. Equivalent bacterial concentrations associated with crustacean zooplankton based on literature data. Bacterial abundances are averaged total bacteria. Only data for whole animals are included. Equivalent bacterial concentration is calculated as (bacterial abundance zooplankter ${ }^{-1}$ ) / zooplankton body volume. Ambient bacterial concentrations are included for comparison. NA: not available. See Table 2 for further details

\begin{tabular}{|c|c|c|c|c|c|}
\hline Zooplankton type & $\begin{array}{l}\text { Zooplankton } \\
\text { body volume } \\
\text { (ml) }\end{array}$ & $\begin{array}{c}\text { Bacterial } \\
\text { abundance } \\
\text { (cells ind. }^{-1} \text { ) }\end{array}$ & $\begin{array}{c}\text { Equivalent bacterial } \\
\text { concentration } \\
\left(\text { cells ml }{ }^{-1}\right)\end{array}$ & $\begin{array}{l}\text { Ambient bacterial } \\
\text { concentration } \\
\left(\text { cells ml }{ }^{-1}\right)\end{array}$ & Source \\
\hline Acartia tonsa & ${ }^{\mathrm{a}} 2.5 \times 10^{-5}$ & $\mathrm{~b}_{2} .0 \times 10^{5}$ & $8 \times 10^{9}$ & ${ }^{\mathrm{c}} 1 \times 10^{7}$ & Hansen \& Bech (1996) \\
\hline dArtemia franciscana & e $3.1 \times 10^{-5}$ & $\mathrm{f}_{1.7 \times 10^{4}}$ & $5.6 \times 10^{8}$ & NA & Olsen et al. (2000) \\
\hline${ }^{g} A$. franciscana & e $3.1 \times 10^{-5}$ & ${ }^{\mathrm{f}} 3.3 \times 10^{3}$ & $9.7 \times 10^{7}$ & NA & Olsen et al. (2000) \\
\hline$>202 \mu \mathrm{m}$ & $\mathrm{h}_{2.5} \times 10^{-5}$ & i $9.6 \times 10^{6}$ & $3.8 \times 10^{11}$ & NA & Heidelberg et al. (2002) \\
\hline $64-202 \mu \mathrm{m}$ & $\mathrm{j} 8.3 \times 10^{-6}$ & ${ }^{\mathrm{k}} 2.9 \times 10^{5}$ & $3.4 \times 10^{10}$ & NA & Heidelberg et al. (2002) \\
\hline A. tonsa & $2.5 \times 10^{-5}$ & $2.0 \times 10^{3}-4.5 \times 10^{5}$ & $8 \times 10^{7}-1.8 \times 10^{10}$ & NA & Tang (2005) \\
\hline \multicolumn{6}{|l|}{ Calanus helgolandicus +} \\
\hline C. finmarchicus & ${ }^{1} 5.5 \times 10^{-4}$ & $1.9 \times 10^{5}$ & $3.5 \times 10^{8}$ & $\mathrm{~m}_{1.4 \times 10^{5}-5 \times 10^{5}}$ & Møller et al. (2007) \\
\hline Daphnia cucullata & $\mathrm{n}_{1} 1.2 \times 10^{-4}$ & $1.0 \times 10^{5}-3.9 \times 10^{5}$ & $0.8 \times 10^{9}-3.2 \times 10^{9}$ & ${ }^{\circ} 3.4 \times 10^{6}$ & Tang et al. (2009a) \\
\hline Eudiaptomus gracilis & $\mathrm{p} 1.2 \times 10^{-4}$ & $1.7 \times 10^{5}-4.3 \times 10^{5}$ & $2.0 \times 10^{9}-5.1 \times 10^{9}$ & $3.4 \times 10^{6}$ & Tang et al. (2009a) \\
\hline Diaphanosoma brachyurum & $\mathrm{q} 2.5 \times 10^{-5}$ & $3.3 \times 10^{5}$ & $1.3 \times 10^{10}$ & $3.4 \times 10^{6}$ & Tang et al. (2009a) \\
\hline \multicolumn{6}{|c|}{ a Body volume of $A$. tonsa was estimated by Tang et al. (2001) } \\
\hline \multicolumn{6}{|c|}{${ }^{\mathrm{b} B a c t e r i a l}$ abundance is from body surface and intestine combined based on acridine orange direct count } \\
\hline \multicolumn{6}{|c|}{ cAmbient bacterial concentration is based on acridine orange direct count } \\
\hline \multicolumn{6}{|c|}{${ }^{\mathrm{d}}$ Data are for $2 \mathrm{~d}$ old starved nauplii with mean body length $1.07 \mathrm{~mm}$} \\
\hline \multicolumn{6}{|c|}{${ }^{e}$ Body volume is estimated from body length as $V=a L^{3}$ using scaling factor (a) for $A$. tonsa $\left(V=2.5 \times 10^{-5} \mathrm{ml}, L=1 \mathrm{~mm}\right.$; Tang et al. 2001$)$} \\
\hline \multicolumn{6}{|c|}{ fBacterial abundance is for 'Bacteria' } \\
\hline \multicolumn{6}{|c|}{${ }^{9}$ Data are for $2 \mathrm{~d}$ old fed nauplii with mean body length $1.07 \mathrm{~mm}$} \\
\hline \multicolumn{6}{|c|}{ hody volume per zooplankter is assumed to be same as for $A$. tonsa } \\
\hline \multicolumn{6}{|c|}{ 'Bacterial abundance is average 'Bacteria' abundance for zooplankton $>202 \mu \mathrm{m}$} \\
\hline \multicolumn{6}{|c|}{${ }^{\mathrm{j} B o d y}$ volume per zooplankter is assumed to be one-third of that for $A$. tonsa } \\
\hline \multicolumn{6}{|c|}{ kBacterial abundance is average 'Bacteria' abundance for zooplankton $64-202 \mu \mathrm{m}$} \\
\hline \multirow{2}{*}{\multicolumn{6}{|c|}{$\begin{array}{l}{ }^{1} \text { Body volume of } C \text {. helgolandicus and } C \text {. finmarchicus is estimated from body length }(\sim 2.8 \mathrm{~mm}) \text { using scaling factor for } A \text {. tonsa } \\
{ }^{\mathrm{m}} \text { Ambient bacterial concentration is based on flow cytometry }\end{array}$}} \\
\hline & & & & & \\
\hline \multicolumn{6}{|c|}{${ }^{\mathrm{n} B o d y}$ volume of $D$. cucullata is estimated from body length $(\sim 1.7 \mathrm{~mm})$ using scaling factor for $A$. tonsa } \\
\hline \multicolumn{6}{|c|}{${ }^{\circ}$ Ambient bacterial concentration is based on 4',6-diamidino-2-phenylindole (DAPI) direct count } \\
\hline \multicolumn{6}{|c|}{ "Body volume of $E$. gracilis is estimated from body length $(\sim 1.5 \mathrm{~mm})$ using scaling factor for $A$. tonsa } \\
\hline qBody volume of $D$. brachyur & rum & & & & \\
\hline
\end{tabular}

\section{BACTERIAL ASSOCIATION WITH LIVE ZOOPLANKTON}

Chemotactic bacteria actively attach and colonize surfaces (e.g. Kiørboe et al. 2002 for aggregates; Carman \& Dobbs 1997 for metazoans) by following chemical and perhaps hydrodynamic cues. Several studies have demonstrated that various zooplankton species, especially crustaceans, from different aquatic environments are densely colonized by bacteria (Table 2). However, many of the early studies did not give information on the phylogenetic affiliation of these attached bacteria, were biased by the use of culture-dependent methods, or were restricted to specific bacterial phylotypes.

Recent studies using culture independent methods have revealed much more diverse bacterial communities associated with both marine and freshwater zooplankton. Using CARD-FISH, Peter \& Sommaruga (2008) found 4 groups of bacteria in freshwater crustacean zooplankton guts: Cytophaga-Flavobacteria and Alpha-, Beta-, and Gammaproteobacteria. Using a combination of culturing techniques and 16S rRNA sequencing, Schuett \& Doepke (2009) identified 21 bacterial species from 4 cnidarian species, including 2 planktonic forms. These bacteria formed 4 closely related groups of Gammaproteobacteria (Pseudoalteromonas tetraodonis/P. elyacovii/P. haloplanctis; Shewanella sairae/S. marinintestina; S. waksmanii/S. surugaensis/S. kaireiae; and Vibrio splendidus/V. lentus/ $V$. tasmaniensis/ $V$. kanaloae), in addition to species belonging to Bacillus subtilis (Firmicutes), Ilyobacter psychrophilus (Fusobacterium), and Arcobacter butzleri (Epsilonproteobacteria). Eleven of these isolates have been recently described as novel species. Additionally, 4 of the sequenced 16S rDNA fragments from 2 Cyanea species had extremely low relationships to their next relatives and hence represented members of the endobiotic 'terra incognita.' Based on 16S rRNA, Grossart et al. (2009) recovered 36 discrete phylogenetic units from 2 freshwater crustacean zooplankton species that belonged to 6 major bacterial groups (Actinobacteria, Firmicutes, Bacteroidetes, 


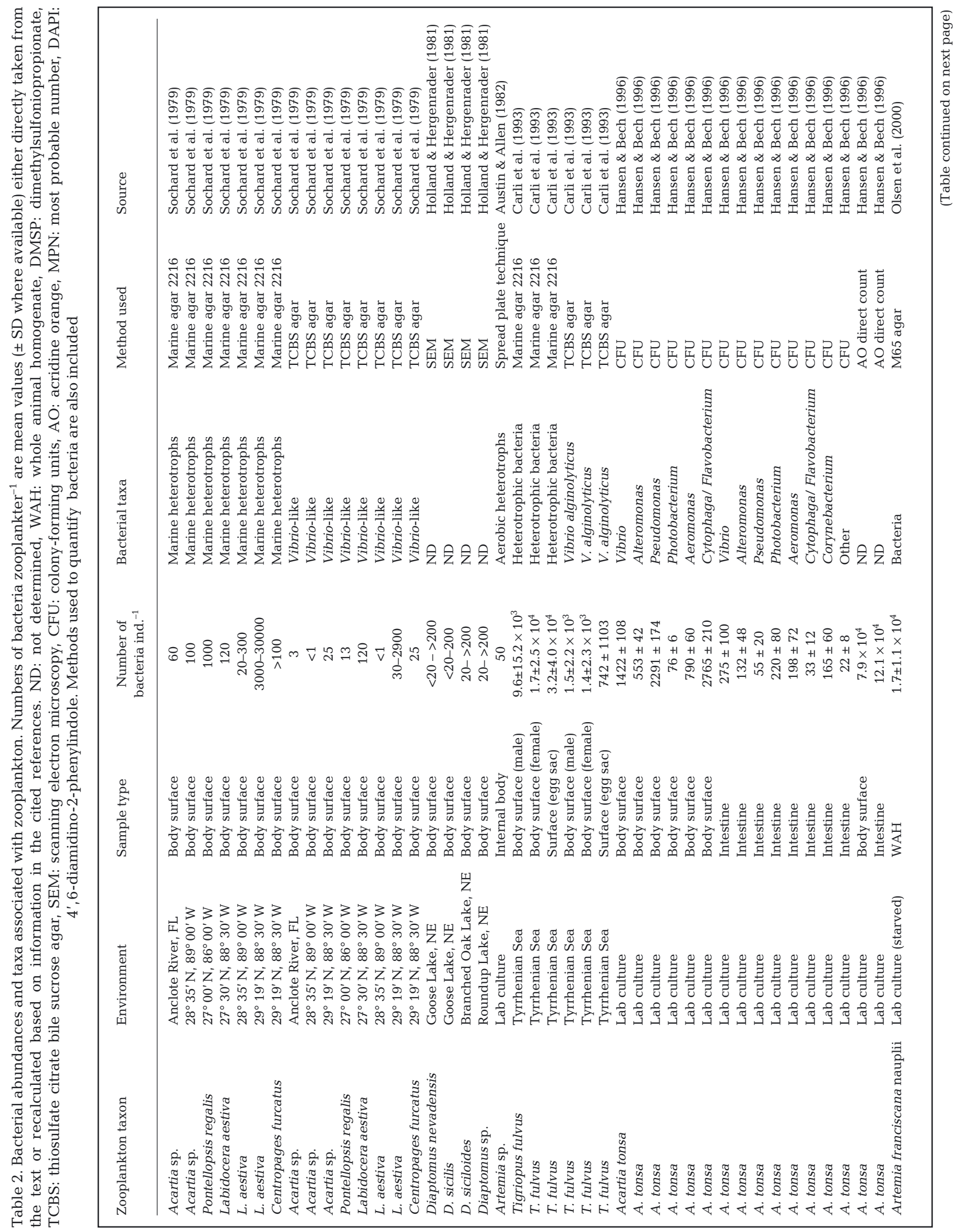




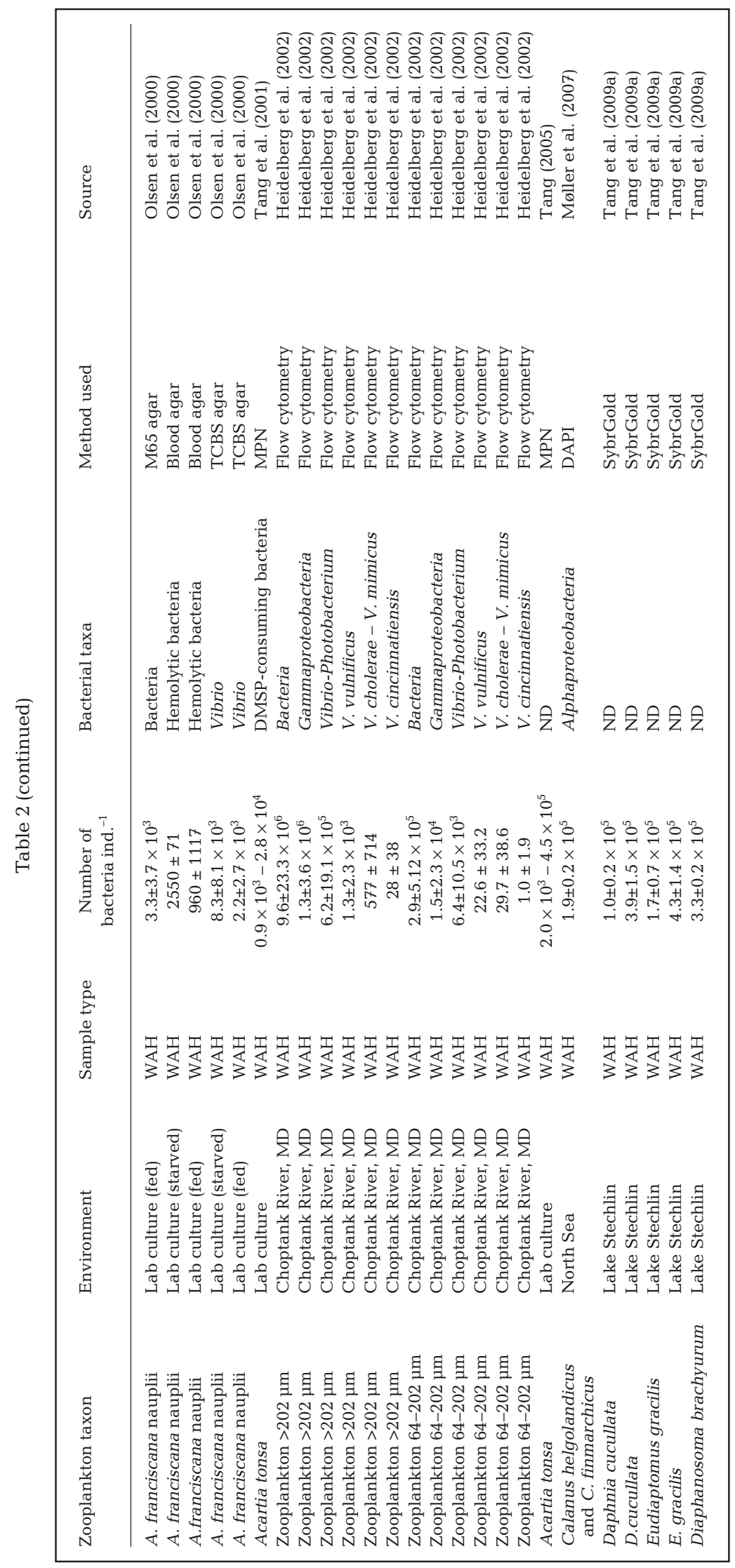

Alpha-, Beta-, and Gammaproteobacteria). Using the same technique, Tang et al. (2009b) identified 37 discrete phylogenetic units from the marine copepod Acartia tonsa that belonged to 3 major bacteria groups (Alpha- and Gammaproteobacteria, Bacteroidetes). Surprisingly, Møller et al. (2007) found only 3 different Roseobacter species on Calanus spp. in the North Sea using similar methods. These findings indicate that Alphaproteobacteria are an important component of the zooplankton-associated bacterial community, which can vary greatly in richness and phylotype composition among zooplankton species, sampling location, and time.

Zooplankton-associated bacteria must also exist in a free-living stage if they are to maintain a viable population beyond the lifetime of the host. For many symbiotic bacteria such as Vibrio fischeri on the squid Euprymna scolopes (Koropatnick et al. 2004), it has been shown that the bacterial symbiont is frequently released into the surrounding water to allow for colonization of other hosts. Earlier studies have shown that zooplankton bodies and the surrounding water share similar bacterial groups but in different proportions (Sochard et al. 1979, Delille \& Razouls 1994, Hansen \& Bech 1996), suggesting an active exchange of bacteria between the 2 compartments, but that their different physical-chemical conditions tend to favor different bacterial groups.

Separation of epibionts and gut microflora is difficult in practice, but the latter are expected to be more directly affected by the host's feeding activity. Harris (1993) proposed a conceptual model that differentiates between transient and resident gut microflora associated with invertebrates: Resident bacteria are persistently present in the gut, whereas transient bacteria do not form stable populations within the gut. Empirical evidence in support of this view is provided by 2 recent studies. When the copepod Acartia tonsa was feeding on different axenic phytoplankton diets, the bacterial diversity associated with the copepod decreased and converged, indicating the presence of a rather stable resident bacterial community (Tang et al. 2009b). In 
contrast, the bacterial diversity greatly diverged and several species such as Pseudoalteromonas, Sulfitobacter, and Roseobacter only appeared when the copepod was feeding on xenic phytoplankton diets, indicating that many of the transient bacteria either actively attached to the animal's body surfaces or were passively ingested (Tang et al. 2009b). Similarly, in a field study, Grossart et al. (2009) observed that the bacterial diversity associated with freshwater zooplankton (Thermocyclops oithonoides and Bosmina coregoni) decreased after gut evacuation. In addition, these authors found that the magnitude of change in bacterial diversity induced by gut evacuation was smaller for zooplankton from an oligotrophic lake versus those from a eutrophic lake. This suggests that the resident bacterial communities behave differently even for the same zooplankton species when living in different environments.

\section{ZOOPLANKTON AS MICROBIAL REACTORS}

Both resident and transient bacteria may take advantage of the rich organic environments provided by zooplankton and attain higher growth rates than free-living bacteria. For example, Carman (1994) demonstrated that nitrogen excretion by copepods stimulates the growth of epibiotic bacteria. Tang (2005) further developed the concept that live copepods act as a reactor for bacterial colonization and growth. In a nutritionally dilute environment, copepods through feeding concentrate organic matter into their guts, which their gut microflora can exploit to attain high growth rates. For gut bacteria (transient and resident) to exploit the ingested materials, they must first survive digestion by the host. Several studies (e.g. King et al. 1991, Plante \& Shriver 1998) have shown that many bacteria, including cyanobacteria (Friedland et al. 2005), can survive zooplankton gut passage, and may then gain access to specific resources that are otherwise limiting in the surrounding water. For example, dimethylsulfoniopropionate (DMSP) is produced by many marine phytoplankton species (Keller \& KorjeffBellows 1996) and is a substrate for DMSP-consuming bacteria (DCB; e.g. Diaz et al. 1992, Visscher et al. 1992). However, direct release of DMSP from actively growing phytoplankton is negligible (Keller \& KorjeffBellows 1996), and the half-saturation constant for free-living DCB in coastal to oligotrophic waters (24 to $>500 \mathrm{nM}$ ) is 5- to 50-fold higher than the dissolved DMSP concentrations (Ledyard \& Dacey 1996), indicating substrate limitation in ambient water. Through feeding, zooplankton can liberate DMSP from phytoplankton cells and accumulate it in their guts to $\mu \mathrm{M}$ to mM levels (Tang et al. 1999), which would allow for maximum turnover by DCB. DCB have indeed been isolated from copepod bodies, and their abundance increased 17 to 30 times when the copepods were fed DMSP-containing food (Tang et al. 2001).

Most copepods have a short gut passage time such that ingestion is tightly coupled with egestion (Dam \& Peterson 1988, Besiktepe \& Dam 2002). Hence gut bacteria also face the challenge of being flushed out during egestion. The presence of gut bacteria in zooplankton even after gut evacuation has been reported (Peter \& Sommaruga 2008). Kirn et al. (2005) identified a single bacterial protein that mediates intestinal colonization and attachment to zooplankton and other organisms by binding to a surface sugar on epithelial cells. Nevertheless, the number of habitable sites in the gut is presumably limited, and the amount of enteric bacteria cannot increase indefinitely. Tang (2005) hypothesized that in the absence of an input of foreign bacteria, the amount of enteric bacteria should follow a predictable relationship with a zooplankter's ingestion rate determining the balance between growth as stimulated by substrate input and loss due to mortality and egestion. This prediction was subsequently confirmed in an experimental study using the copepod Acartia tonsa feeding on various axenic algal diets (Fig. 3)

In the same study, Tang (2005) conservatively estimated a growth rate of $0.89 \mathrm{~d}^{-1}$ for the enteric bacteria, which is much higher than the global average growth rate of 0.05 to $0.3 \mathrm{~d}^{-1}$ for pelagic bacteria (Ducklow 1999). The author also observed that bacteria were released together with other fecal materials by the copepods. Because the copepod was fed axenic food in

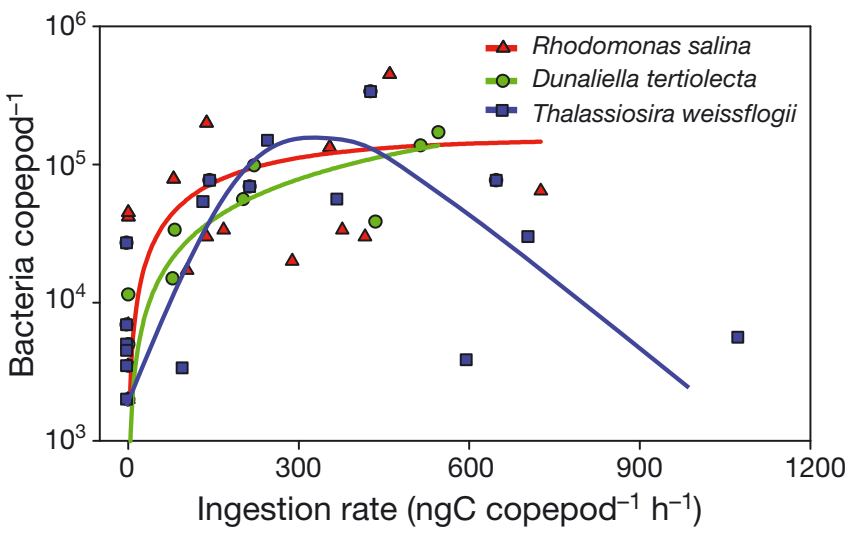

Fig. 3. Bacterial abundance associated with the copepod Acartia tonsa as a function of the copepod's ingestion rate on an axenic diet of Rhodomonas salina, Dunaliella tertiolecta, or Thalassiosira weissflogii. Different symbols represent replicate experiments. Curves are overall fit to the data for each diet type. Without an input of foreign bacteria, feeding by the copepod introduces organic nutrients to its gut, where bacteria can exploit the nutrients and increase in abundance until their growth is balanced or exceeded by loss due to mortality and egestion. Data from Tang (2005) 
the experiments, the release of bacteria via defecation suggests that actively feeding zooplankton function as microincubators and contribute new bacteria to the water column. Although this contribution appears to be small $(<0.1 \%)$ relative to the ambient bacterial standing stock, defecation and detachment may serve as important mechanisms for inoculating different parts of the water column (Grossart et al. 2010).

\section{ZOOPLANKTON AS A SELECTIVE FORCE FOR BACTERIA}

The exterior as well as the interior of a zooplankter provide specific habitats for aquatic bacteria. For example, bacteria attached to the surface of a zooplankter may experience a changing hydrodynamic environment due to the host's movement (Lawrence \& Caldwell 1987) and must also adapt to the specific surface property (Dunne 2002). The reactive dissolved organic carbon (DOC) pool in pelagic systems is mainly composed of molecules such as carbohydrates, amino acids, fatty acids, hydrocarbons, and steroids, and they usually account for a small fraction of total DOC in the water column $(<15 \%$; Benner 2002). In contrast, reactive DOC (including amino acids and carbohydrates) in the vicinity of zooplankton occurs in much higher amounts due to active excretion and sloppy feeding of the zooplankton, and this could become available for attached and even free-living bacteria (Peduzzi \& Herndl 1992, Hansson \& Norrman 1995, Møller et al. 2003, Møller 2005). In an experimental mesocosm study, however, Kragh et al. (2006) demonstrated that the presence of zooplankton leads to an accumulation of less labile aldoses, indicating that zooplankton affect the quantity and quality of the DOC pool in the surrounding water. As a result, release and accumulation of specific DOC compounds in the presence of zooplankton potentially selects for specific bacterial phylotypes, e.g. opportunistic bacteria (Eilers et al. 2000, Cottrell \& Kirchman 2003).

Enteric bacteria, on the other hand, will experience high organic matter and nutrient concentrations and large changes in $\mathrm{pH}$ and oxygen availability during gut passage. The organic-rich, low oxygen environment inside a zooplankter's gut and fecal pellets may favor anaerobic bacterial processes that are otherwise not feasible in the oxygenated water column. Indeed, an important observation in the past decades is the presence of strict anaerobes inside the zooplankton gut and fecal pellets (Bianchi et al. 1992, Marty 1993, Proctor 1997, Braun et al. 1999). Globally it is estimated that $12 \%$ of the primary production is consumed, directly or indirectly, by metazoan zooplankton (Calbet 2001). Due to the possible variety of bacterial metabolism associated with zooplankton, these microenvironments represent a platform allowing for inter-linkages of microbial processes in processing and degrading a large fraction of the organic matters in marine and freshwater environments, and support anaerobic processes in an otherwise aerobic environments (Stief et al. 2009). As such they have potentially significant effects on global biogeochemical cycles.

The chemical composition of the zooplankton body as a potential source for bacterial substrates substantially differs from that of phytoplankton biomass. Due to the lack of large amounts of carbohydrate storage products, carbon content of zooplankton is usually lower in relation to nitrogen and phosphorus (Beers 1966). Hence, the zooplankton body itself is a preferential bacterial substrate (see below under 'Zooplankton carcasses'). The chemical composition and availability of zooplankton-derived particulate and dissolved organic matters therefore has major implications for bacterial dynamics and phylotype selection not only on the zooplankton but also in the surrounding water.

\section{ZOOPLANKTON AS A REFUGE FOR BACTERIA}

Previous studies have shown that potentially pathogenic bacteria, e.g. Vibrio spp., find suitable growth conditions in zooplankton bodies (Colwell 1996). Freeliving bacteria are constantly subject to environmental hazards such as predation, viral lysis, and harmful radiation and chemicals, and a zooplankton body may provide a refuge for bacteria against these external hazards. Endosymbiotic bacteria that are commonly found in protozoa have been shown to survive disinfectants that normally kill free-living bacteria, hence posing a great threat to public health (Barker \& Brown 1994, Bichai et al. 2008).

Various disinfection technologies are used commercially to treat ballast water in an attempt to curb the global spread of harmful organisms. Recent experiments by K. W. Tang et al. (unpubl.), however, suggest that bacteria associated with cladocerans and copepods could survive conventional ballast water treatments such as heat, UV radiation, and ozonation even though free-living bacteria and zooplankton themselves did not (Fig. 4). Subsequent discharge of treated ballast water into coastal zones may unknowingly inoculate the local water with potential pathogens carried by zooplankton. Protection by zooplankton may also affect the evolution of local bacterial communities under the influence of other environmental stresses.

While the zooplankton hosts may provide refuge for the associated bacteria, the hosts themselves may also benefit from these bacteria. For example, Rico-Mora \& 


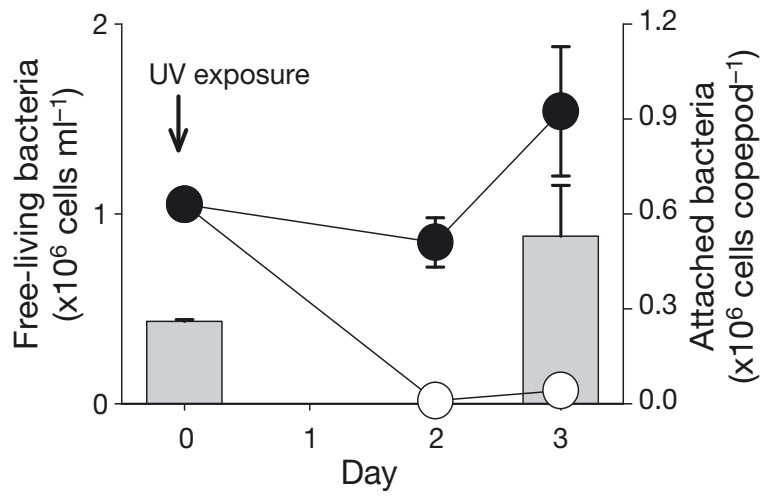

Fig. 4. Zooplankton as a refuge for bacteria. Seawater was exposed to UV for $2 \mathrm{~h}$ on Day 0 with or without the copepod Acartia tonsa. The copepod died after the exposure. Free-living bacteria in the absence of copepod $(O)$ declined significantly after the initial exposure. However, free-living bacteria in the presence of copepod (๑) decreased only slightly and recovered by Day 3. Attached bacteria (bars) also recovered after $3 \mathrm{~d}$. Data from K. W. Tang et al. (unpubl.)

Voltolina (1995) showed that inoculation of the brine shrimp Artemia sp. with bacterial isolates from diatom cultures could significantly improve the survivorship of the animals relative to the bacteria-free control and those challenged with pathogenic Vibrio spp. In addition to being a potential food source or aiding the host's digestion (Fong \& Mann 1980, Wainwright \& Mann

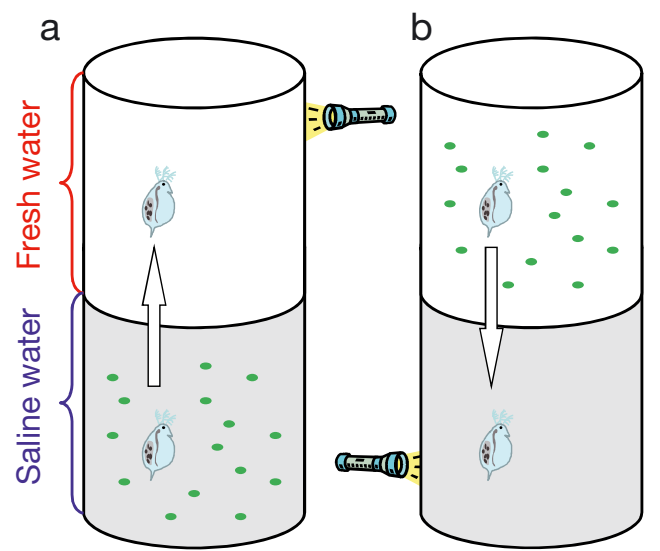

Fig. 5. Vertical dispersal of bacteria by migrating zooplankton. Experiments were conducted in clear plexiglass columns with a stable salinity stratification (2 psu). Green fluorescent protein (GFP)-labeled bacteria (Pimelobacter sp.) were initially added to either (a) the lower or (b) the upper layer. Forty individuals of Daphnia magna, which were positively phototactic, were guided to complete 1 migration cycle (up + down) every $2 \mathrm{~h}$ for $8 \mathrm{~h}$ by a focused light source. Bacterial concentration (cells $\mathrm{ml}^{-1}$; mean $\pm \mathrm{SE}$ ) in the receiving end of the column increased significantly faster when Daphnia were present in both experiments, confirming that migrating Daphnia facilitate vertical dispersal of bacteria in both upward and downward directions. Data from Grossart et al. (2010)
1982), attached benign bacteria may have a probiotic effect and protect the host against pathogenic bacteria (Verschuere et al. 1999, 2000).

\section{BACTERIAL DISPERSAL BY ZOOPLANKTON}

Many zooplankton species perform strong diel, seasonal, or ontogenetic vertical migration, sometimes up to thousands of meters (Lampert 1989, Visser \& Jónasdóttir 1999, Kobari \& Ikeda 2001). In a stratified water column, a migrating zooplankter will be exposed to and subsequently acquire different bacteria between different water layers, and may act as a conveyor belt for dispersing bacteria over vast distances and across boundaries such as the pycnocline. Sinking aggregates perform a similar function (Turley \& Mackie 1995) but primarily in the downward direction (in addition to horizontal advection). In comparison, a zooplankter can migrate both upward and downward multiple times during its lifetime. Therefore, this conveyor belt works much longer than an aggregate and facilitates bacterial exchange in both directions. In a recent experimental study, Grossart et al. (2010) used stratified migration columns and confirmed that migrating zooplankton (Daphnia magna) dispersed bacteria between the separate water layers in both upward and downward directions (Fig. 5), hence confirming the validity of the conveyor belt hypothesis.
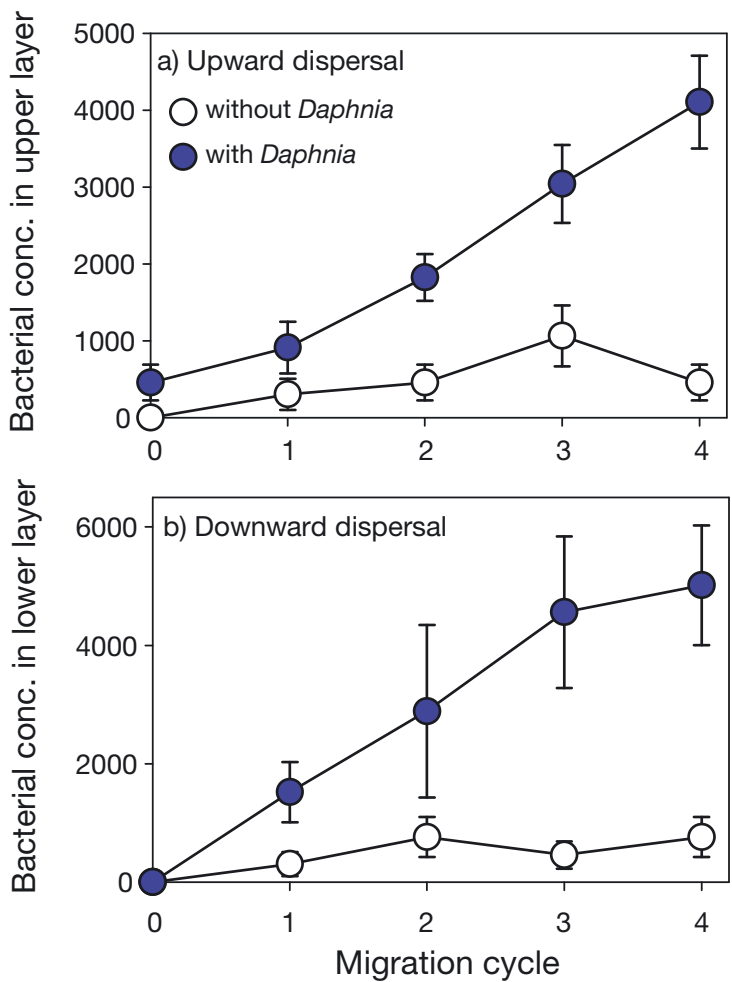
Research on aggregates has shown that bacteria attached to surfaces are capable of quorum sensing via homoserine lactone communication (Gram et al. 2002), which allows them to synchronize specific metabolic processes to maximize their metabolic rate and growth efficiency. In the case of probiotic as well as pathogenic bacteria, this will have important consequences for the environment. Multidrug resistance can frequently be found in bacteria on fish, and it is believed that the increased tolerance to antibiotics and heavy metals is related to the close proximity of resistant and non-resistant bacteria, which allows for increased horizontal gene exchange (e.g. Pathak \& Gopal 2005). Long-range migration by zooplankton and other animal hosts may help the spread of drug-resistant genotypes across a broad geographical range even among otherwise isolated water masses, posing a hidden threat to ecosystem and human health.

\section{OTHER MODES OF ZOOPLANKTON-BACTERIA ASSOCIATION}

\section{Zooplankton feces}

Approximately a third of the food ingested by pelagic organisms is egested as feces (Parsons et al. 1977). Zooplankton such as copepods and salps produce fast-sinking fecal pellets, from tens to thousands $\mathrm{m} \mathrm{d}^{-1}$ (Bruland \& Silver 1981, Komar et al. 1981, Caron et al. 1989), and thus contribute substantially to the 'biological pump' (Cherry et al. 1978). On the other hand, fecal matter may be remineralized by bacteria within the water column (Gowing \& Silver 1983, Jacobsen \& Azam 1984, Caron et al. 1989), reducing the overall vertical flux. This process can be further enhanced by physical breakage of the pellets by zooplankton (Lampitt et al. 1990). Differences in the physical structure of the pellets may also lead to different remineralization rates. For example, a copepod fecal pellet is bound by a peritrophic membrane and may remain intact for a longer time, whereas a salp fecal pellet lacks a membrane and tends to be more brittle.

Fecal matter released by zooplankton often already carries large amounts of bacteria (Turner 1979). For example, the reported equivalent total bacterial concentrations in copepod fecal pellets are $10^{10}$ to $10^{11}$ cells $\mathrm{ml}^{-1}$ for Acartia tonsa (Hansen \& Bech 1996, Thor et al. 2003) and $10^{3}$ to $10^{5}$ cells $\mathrm{ml}^{-1}$ for Temora stylifera (Delille \& Razouls 1994). The latter study also showed that the frequency of dividing bacterial cells and mean bacterial cell volumes increased, respectively, from $3 \%$ and $0.12 \mu \mathrm{m}^{3}$ in seawater to $>6 \%$ and $0.24 \mu^{3}$ in fecal pellets. Previously, it had been thought that bacterial colonization of zooplankton fecal pellets is mainly initiated from the outside by chemotactic bacteria in the surrounding water (Honjo \& Roman 1978, Turner 1979, Jacobsen \& Azam 1984). However, Gowing \& Silver (1983) demonstrated that most of the bacterial colonization is from the inside by enteric and digestion-resistant bacteria. The presence of bacteria in fecal materials produced by copepods feeding on axenic food also confirmed that enteric bacteria can be passed onto fecal pellets (Tang 2005). On the other hand, a study with deposit-feeders showed that bacterial proliferation on egesta was faster than could be explained by growth alone (Plante \& Wilde 2001), indicating that colonization by external bacteria must have also occurred at the same time.

\section{Zooplankton molts}

Chitin is the second-most abundant biogenic polysaccharide on earth after cellulose and hence is among the most abundant and important sources of nutrients and energy in the marine environment (Gooday 1990). Chitin is a major component of the cuticles and exoskeletons of worms, mollusks, and arthropods (Jeuniaux 1982). The annual biosynthesis of chitin has been estimated at 1.4 billion tons in all aquatic environments combined (Cauchie 2002). The dry mass of chitin produced by the planktonic crustacean Euphausia pacifica through molting alone is ca. 5 to 12 million tons annually (Jerde \& Lasker 1966, Jeuniaux 1971). Yu et al. (1991) asserted that chitin production by copepods and other organisms leads to a continuous 'rain' of particulate organic matter. Furthermore, molts (exuviae) of crustacean zooplankton significantly contribute to the formation of macroscopic organic aggregates in marine (Gardner 1977) and freshwater (Grossart et al. 1997, Grossart \& Simon 1998) systems. From an ecological point of view, chitin plays a key role in the biogeochemical cycles of both $\mathrm{C}$ and $\mathrm{N}$, and the rates of chitin production and degradation influence $\mathrm{C}$ and $\mathrm{N}$ pools and their availability (Poulicek et al. 1998, Pruzzo et al. 2008).

In his pioneering in situ study of chitin degradation (practical grade chitin from crustacean shells) using the mesh bag technique, Kirchner (1995) revealed that $90 \%$ of the initial substrate was lost after 3 mo of incubation in seawater at 10 to $18^{\circ} \mathrm{C}$. Other studies also found that several marine bacteria are capable of degrading chitin (Bassler et al. 1991, Keyhani \& Roseman 1999, Ramaiah et al. 2000, Tilly et al. 2001, Itoi et al. 2006), but none of them used natural zooplankton molts as a substrate. Studying bacterial colonization of lake snow in Lake Constance, Weiss et al. (1996) showed that aggregates containing a high fraction of zooplankton exoskeleton during the clear water phase were mainly 
colonized by Proteobacteria of the Alpha (5 to $32 \%$ ), Beta (20 to $60 \%$ ), and Gamma subclasses (6 to $42 \%$ ). In the Delaware estuary, Cottrell \& Kirchman (2003) found chitinase genes in a handful of bacterial groups including Enterobacteriaceae, Alteromondaceae, Vibrioceae, and Alphaproteobacteria of the Roseobacter clade. However, except for Vibrio spp., almost nothing is known about bacterial colonization of zooplankton molts. Tamplin et al. (1990) showed that 4 of 5 clinical $V$. cholerae $\mathrm{O} 1$ strains and endogenous bacteria preferentially attached to zooplankton molts rather than whole animals. $V$. cholerae growing on natural chitin surfaces show coordinated gene expression involved with chitin chemotaxis and adherence as well as the transport and assimilation of $\mathrm{N}$-acetylglucosamine (GlcNAc; Meibom et al. 2004), suggesting that this species is well adapted to using this highly abundant carbon and nitrogen source in aquatic environments.

Using methylumbelliferyl-N, N'-diacetyl-chitobioside, and ${ }^{14} \mathrm{C}$-chitin, Kirchman \& White (1999) showed that bacterial hydrolysis of chitin was always faster than mineralization, resulting in the release of GlcNAc to the surrounding water. On average, however, chitin hydrolysis and uptake accounts for only $10 \%$ of the total bacterial production (Kirchman \& White 1999). Interestingly, Riemann \& Azam (2002) showed not only that roughly a third of all marine bacteria take up GlcNAc, but also that these bacteria are predominantly facultative anaerobes. The capability of fermentative metabolism could be an important adaptation to low oxygen microenvironments in the pelagial associated with molts, fecal pellets, and zooplankton gut.

\section{Zooplankton carcasses}

Traditional zooplankton sampling tends to ignore the presence of carcasses due to methodological difficulties in separating live and dead animals. Nevertheless, zooplankton carcasses have been observed worldwide (Tang et al. 2009a), and simple staining methods are now available for distinguishing between live and dead crustacean zooplankton in freshwater and marine systems (Bickel et al. 2009, Elliott \& Tang 2009). Using these staining methods, it has been shown that up to $40 \%$ of the zooplankton (copepods and daphnids) can be dead in situ (Bickel et al. 2009, Elliott \& Tang 2009). This is of particular interest since carcasses of both crustacean and non-crustacean zooplankton species represent concentrated reservoirs of labile organic substrates for water column bacteria (Tang et al. 2006a, Titelman et al. 2006, Bickel \& Tang in press). Previous experiments have shown that zooplankton carcasses are rapidly colonized and decomposed by bacteria mainly from the outside (Harding 1973, Bickel \& Tang in press), with the caveat that some of the epibionts could have been killed by the treatment that produced the zooplankton carcasses, leading to an underestimation of the contribution to the decomposition process by epibionts. The initial increase in bacterial abundance during the carcass decomposition process is temperature-dependent but is less dependent on aerobic versus anaerobic conditions (Tang et al. 2006b). Tang et al. (2009a) observed that cladoceran carcasses were colonized by bacteria faster than copepod carcasses both in the laboratory and in the field. In addition, carcasses suspended in a eutrophic lake had a higher average carbon loss rate than those suspended in an oligotrophic lake. These differences suggest that exploitation of zooplankton carcasses by bacteria depends on carcass type and environmental conditions.

In addition to bacteria, fungi are also able to colonize and decompose zooplankton carcasses, especially when bacterial activities are suppressed (Tang et al. 2006b). The exoskeleton of zooplankton contains a large fraction of chitin and can be densely colonized by aquatic fungi. Chitin is often used for isolation and cultivation of a variety of fungi, and fungal chitinases are well known to efficiently degrade chitin (reviewed by Wurzbacher et al. 2010). Hence zooplankton molts and carcasses are important organic carbon sources not solely for bacteria but also for fungi.

Although these carcass-colonizing microbes exhibit both very high protease and lipase activities, carcass protein decomposition is faster than lipid decomposition (Bickel \& Tang in press), resulting in differential remineralization and preservation of different biochemical components of the carcasses. Analysis of similarity (ANOSIM) of denaturing gradient gel electrophoresis (DGGE) banding patterns revealed that bacterial communities on decomposing zooplankton carcasses rapidly diverged from those in the surrounding water, but remained similar among different types of zooplankton carcasses (Tang et al. 2009a). These observations demonstrate that zooplankton carcasses are decomposed by similar bacterial groups and serve as important microbial microenvironments where rapid and efficient local selection takes place.

In many lakes, crustacean zooplankton populations can suffer high and abrupt mortality due to starvation and diseases resulting in the phenomenon of 'midsummer decline' (Gries \& Güde 1999, Hülsmann \& Weiler 2000, Hülsmann \& Voigt 2002). Massive die-off of zooplankton will produce abundant zooplankton carcasses as microbial hotspots to fuel water column and benthic bacterial production. Unfortunately, in most traditional microbial studies, these hotspots have been excluded by pre-filtration of water samples.

There are very few published studies on the potentially important aspect of jellyfish blooms, i.e. the fate 
of jellyfish-derived organic matter. Jellyfish carcasses can impact microbial processes, causing significant changes to nitrogen and oxygen dynamics in the surrounding environment (Pitt et al. 2009, West et al. 2009) as well as the composition and activity of the ambient bacterial community (Riemann et al. 2006, Titelman et al. 2006, Tinta et al. 2010). Some preliminary results of the bacterial community structure as measured by DGGE indicated differences in the bacterial community response between ecosystems where medusae occur throughout the year and areas where they occur only seasonally (Tinta et al. 2010). Mass deposition of jellyfish and salp carcasses has also been hypothesized to fuel the microbial food web in the seabed (Billet et al. 2006, Lebrato \& Jones 2009).

\section{FUTURE CHALLENGES AND OPPORTUNITIES}

The available, albeit limited, quantitative data in the literature (Table 2) indicate large variability in zooplankton-associated bacterial abundance in space and in time, as well as among zooplankton species. Understanding what factors contribute to this variability will be an important task for researchers. Because zooplankton likely acquire bacteria via direct bacterial attachment and ingestion, zooplankton-associated bacterial abundance could be dependent on ambient free-living and particle-attached bacterial concentrations. Differences between zooplankton species may be related to the zooplankton feeding strategy (e.g. non-selective versus selective feeders) and body size. Because both bacteria and zooplankton reside within a viscous environment, their encounter and interactions will also be influenced by ambient flow. The use of new in situ flow visualization experiments (Dabiri et al. 2005, Costello et al. 2008) and new mechanical models based on hydrodynamic patterns might explain the relationship between flow, zooplankton, and microbial community ecology. Simple and readily testable hypotheses as such may unveil some general patterns in zooplankton-bacteria associations.

Past research on zooplankton-bacteria associations is largely limited to crustacean zooplankton, and extension of sampling effort to gelatinous zooplankton and microzooplankton is much needed. Many investigators used whole animals or homogenates, and therefore their measurements do not separate epibionts and gut microflora (Tables $1 \& 2$ ). Because the 2 communities are exposed to very different environments, separation between the two, for example by microdissection of the zooplankton gut (Peter \& Sommaruga 2008), will be necessary for proper understanding of their respective physiology and ecology.
While previous work has tended to rely on culturedependent methods and focused on a few pathogenic species (most notably Vibrio spp.), modern cultureindependent molecular techniques have revealed very diverse assemblages of bacteria associated with marine and freshwater zooplankton, many of whose pathogenicity and other characteristics remain unexplored. Techniques such as metagenome sequencing, bioinformatics, systems biology, and new statistical approaches should allow for detailed analyses of changes in bacterial community structure in relation to the life cycle and behavior of the zooplankton host. Study of the metatranscriptome and proteome of these complex bacterial communities will also help us understand their ecological roles on the hosts as well as in the surrounding water, and when combined with single cell techniques such as Raman microscopy and NanoSims (secondary ion mass spectrometry), it will even be possible to quantify microbial processes in and on live zooplankton. Microautoradiography in combination with fluorescence in situ hybridization (MARFISH) can be used to more accurately measure specific substrate uptake and growth of bacteria associated with the different zooplankton body parts.

Although the presence of strict anaerobes inside the zooplankton gut has been known for some time (e.g. Proctor 1997), the physical-chemical characteristics of a zooplankter's gut remain poorly known. These environments may vary according to the feeding activities and physiology of the zooplankton and subsequently select for different bacterial communities. The use of $\mathrm{pH}$ - or oxygen-sensitive chemicals provides only a crude characterization of the gut environments (e.g. Pond et al. 1995). An alternative is to use microsensors to generate detailed profiles of the gut for $\mathrm{pH}$, oxygen, nitrous oxides, sulfide, and other chemical species, which has been done successfully with terrestrial insects (e.g. Bignell \& Anderson 1980). Detailed characterization of the gut environment in combination with molecular analysis of the gut microflora would allow researchers to study the selection and adaption of different bacteria in this unique microenvironment.

In addition to live zooplankton, other microenvironments such as zooplankton fecal pellets, molts, and carcasses also warrant further study. Although bacterial activities on zooplankton fecal pellets have been intensively studied in the past decades, they are largely limited to copepod fecal pellets. Fecal pellets produced by other zooplankton groups have different sizes and textures, but information on their bacterial activities is scarce. The reported occurrence of strict anaerobes in zooplankton fecal pellets (e.g. Bianchi et al. 1992, Marty 1993) suggests that, similar to the gut, fecal pellets provide a semi-enclosed environment 
where microbial activities proceed very differently than in the well oxygenated surface water. Microbial activities in fecal pellets can contribute to water column denitrification and methane production (Oremland 1979, de Angelis \& Lee 1994, Michotey \& Bonin 1997), but the internal oxygen environment of fecal pellets remains largely unknown, a gap that can be filled by microsensor profiling combined with advanced molecular analysis.

To our knowledge, bacterial colonization of crustacean zooplankton molts and carcasses has not been studied in detail using modern molecular techniques such as metagenomic and metatranscriptomic approaches. This is surprising, considering the global abundance of chitin and that chitin degradation by aquatic bacteria is essential for returning carbon and nitrogen to aquatic nutrient cycles (Kirchner 1995, Flintoft 2004). Zooplankton carcasses may be of particular importance at times when other bacterial substrates are limited, e.g. during the clear water phase which follows the phytoplankton spring bloom in many temperate lakes. Besides bacteria, aquatic fungi are also capable of degrading chitin (Tang et al. 2006b, Wurzbacher et al. 2010), although their ecological role in remineralizing zooplankton molts remains to be explored. The combination of both molecular and ecological methods will provide a better understanding of how zooplankton molts and carcasses can affect bacterial community composition, microbial organic matter transformation, and biogeochemical cycling in the pelagic zone.

Comparative studies of different carcass types are also needed. For example, gelatinous zooplankton carcasses lack a chitinous covering, and presumably decompose more readily than crustacean carcasses, yet the limited data available have suggested otherwise (Bickel \& Tang in press). Bacterial decomposition of jellyfish is also of particular interest because of the perceived increase in occurrence of jellyfish 'blooms' worldwide (Mills 2001, Purcell et al. 2007). Because most jellyfish species have few natural predators, their carcasses at the termination of a bloom will likely have large impact on the water column and benthic microbial communities (Titelman et al. 2006, Tinta et al. 2010).

The probiotic versus harmful effects of different bacterial species on the zooplankton hosts have far-reaching implications for aquaculture practices as well as zooplankton ecophysiology and ecosystem health. So far, research on this topic is largely restricted to brine shrimp because of the relative ease with which commercially available encysted eggs may be disinfected to produce bacteria-free animals for exposure experiments (e.g. Verschuere et al. 1999, 2000). Although copepods and daphnids, the most representative of metazoan zooplankton in aquatic environments, do produce encysted resting eggs (e.g. Uye 1985, Alekseev \& Lampert 2001), these resting eggs are not easily available, and the feasibility of using them to produce bacteria-free animals has not been carefully evaluated. The difficulty in producing bacteria-free zooplankton cultures will limit our ability to study how different bacterial species or assemblages affect the host. To partially circumvent this problem, comparative studies of the physiology and ecology of the same zooplankton species but colonized by different bacterial assemblages may provide helpful insights.

\section{CONCLUDING REMARKS}

Increasing specialization in science has accelerated the advances of many research disciplines, but at the same time has encouraged an increasingly fragmented and incomplete understanding of the natural world. This is evident in the traditional separation of 'microbial ecology' and 'zooplankton ecology.' As a consequence, we may have missed a large portion of the microbial world and hence are still far from fully understanding biodiversity and functioning of the ecosystem. Bridging these disciplines requires an unconventional way of thinking and approach to research, and recent studies on this topic have laid the necessary foundation for it.

Our review shows that bacteria colonize and interact with zooplankton in many ways with far-reaching implications for microbial production, dispersal, diversity maintenance, evolution, and biogeochemical fluxes (Fig. 6). Nevertheless, available information is still limited to only a few zooplankton groups and a few environments, in particular copepods in coastal and estuarine waters. Because different zooplankton taxa can have very different life history traits that can influence the form of zooplankton-bacteria interactions, extension of research efforts to other zooplankton taxa is much needed. In the oligotrophic open ocean where nutrients are limiting in the water column, direct association with zooplankton may become more important for bacteria (cf. Grossart et al. 2009). Recent and continuous methodological advances in microbiology and microbial ecology will allow researchers to study these interactions in unprecedented detail. As the complexity of zooplankton-bacteria interactions continues to unfold, new ecological concepts and models will be needed to help researchers integrate the new information into our current understanding of the ecosystem. We hope that this article will encourage more collaboration between zooplankton ecologists and microbial ecologists to advance this exciting and promising research topic. 


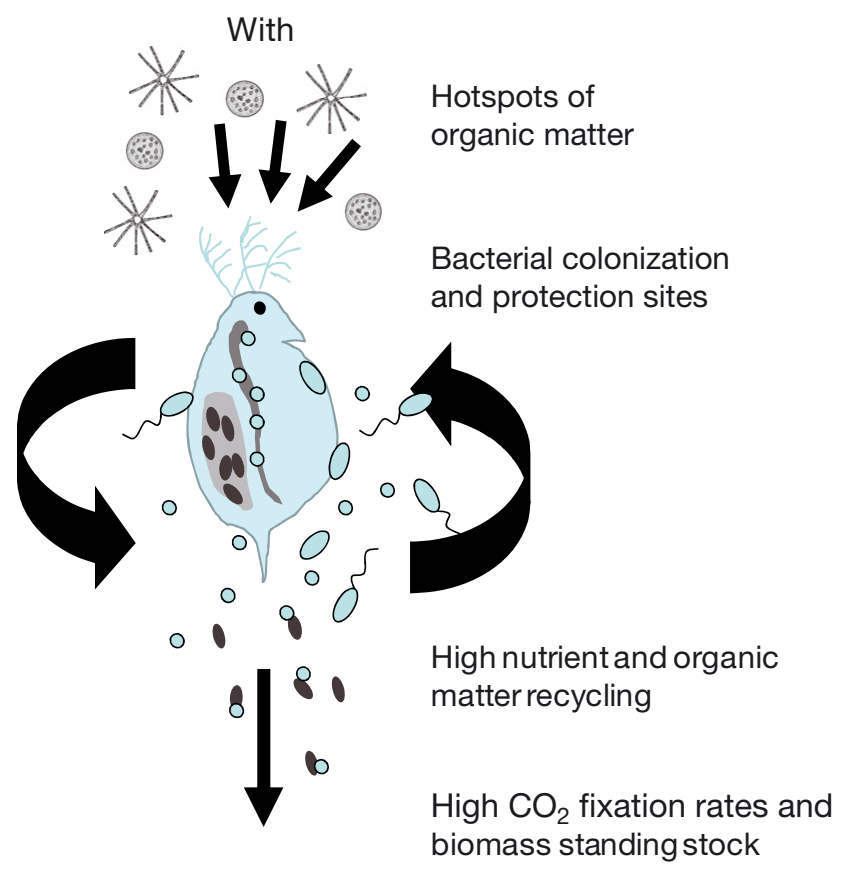

High C-Sequestration
Without

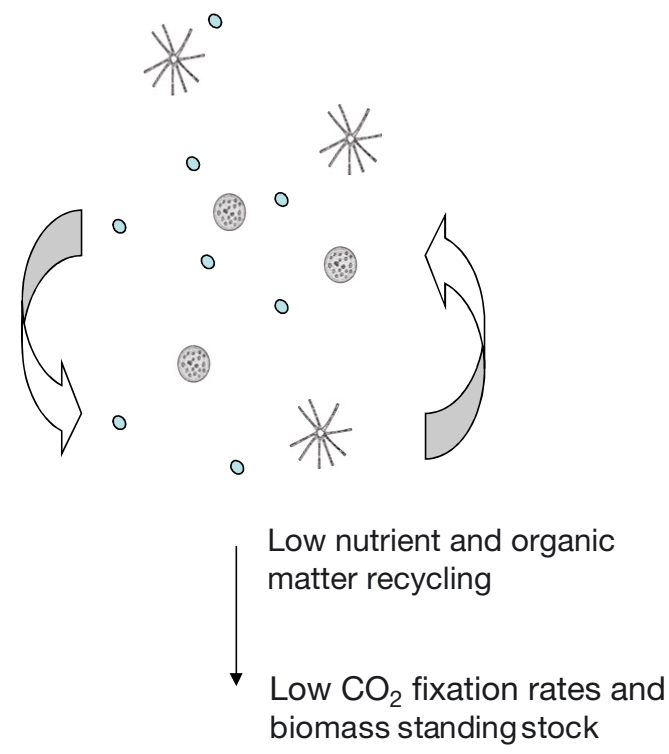

Low C-Sequestration

Fig. 6. Aquatic biogeochemical processes as influenced by zooplankton. Zooplankton have been shown to increase particulate organic matter removal, nutrient regeneration, and vertical carbon flux. These processes will be modulated by bacteria associated with the zooplankton and fecal matter. Zooplankton and fecal matter also provide a microenvironment where bacterial production, diversity maintenance, and evolution may proceed differently than in the surrounding water

Acknowledgements. K.W.T. received support from the U.S. National Science Foundation (award OCE-0814558). H.P.G. was supported by grants GR1540/11-2 and PA1655/1-1 from the German Science Foundation (DFG). We thank E. Mach and C. Freund for assistance.

\section{LITERATURE CITED}

Alekseev V, Lampert W (2001) Maternal control of restingegg production in Daphnia. Nature 414:899-901

$>$ Austin B, Allen DA (1982) Microbiology of laboratory-hatched brine shrimp (Artemia). Aquaculture 26:369-383

>Azam F, Malfatti F (2007) Microbial structuring of marine ecosystems. Nat Rev Microbiol 5:782-791

> Barker J, Brown MRW (1994) Trojan horse of the microbial world: protozoa and the survival of bacterial pathogens in the environment. Microbiology 140:1253-1259

Bassler BL, Gibbons PJ, Yu C, Roseman S (1991) Chitin utilization by marine bacteria. Chemotaxis to chitin oligosaccharides by Vibrio furnissii. J Biol Chem 266:24268-24275

Beers JR (1966) Studies on the chemical composition of the major zooplankton groups in the Sargasso Sea off Bermuda. Limnol Oceanogr 11:520-528

Benner R (2002) Chemical composition and reactivity. In: Hansell DA, Carlson CA (eds) Biogeochemistry of marine Dissolved Organic Matter. Academic Press, Amsterdam, p 59-90

Besiktepe S, Dam HG (2002) Coupling of ingestion and defecation as a function of diet in the calanoid copepod Acartia tonsa. Mar Ecol Prog Ser 229:151-164
Bianchi M, Marty D, Teysslé JL, Fowler SW (1992) Strictly aerobic and anaerobic bacteria associated with sinking particulate matter and zooplankton fecal pellets. Mar Ecol Prog Ser 88:55-60

> Bichai F, Payment P, Barbeau B (2008) Protection of waterborne pathogens by higher organisms in drinking water: a review. Can J Microbiol 54:509-524

Bickel SL, Tang KW (2010) Microbial decomposition of proteins and lipids in copepod versus rotifer carcasses. Mar Biol 157:1613-1624

> Bickel SL, Tang KW, Grossart HP (2009) Use of aniline blue to distinguish live and dead crustacean zooplankton composition in freshwaters. Freshw Biol 54:971-981

- Bignell DE, Anderson JM (1980) Determination of $\mathrm{pH}$ and oxygen status in the guts of lower and higher termites. J Insect Physiol 26:183-188

Billet DSM, Bett BJ, Jacobs CL, Rouse IP, Wigham BD (2006) Mass deposition of jellyfish in the deep Arabian Sea. Limnol Oceanogr 51:2077-2083

Braun ST, Proctor LM, Zani S, Mellon MT, Zehr JP (1999) Molecular evidence for zooplankton-associated nitrogenfixing anaerobes based on amplification of the nifH gene. FEMS Microbiol Ecol 28:273-279

Bruland KW, Silver MW (1981) Sinking rates of fecal pellets from gelatinous zooplankton (salps, pteropods, doliolids). Mar Biol 63:295-300

Calbet A (2001) Mesozooplankton grazing effect on primary production: a global comparative analysis in marine ecosystems. Limnol Oceanogr 46:1824-1830

> Carli A, Pane L, Casareto L, Bertone S, Pruzzo C (1993) Occurrence of Vibrio alginolyticus in Ligurian coast rock 
pools (Tyrrhenian Sea, Italy) and its association with the copepod Tigriopus fulvus. Appl Environ Microbiol 59: 1960-1962

> Carman KR (1994) Stimulation of marine free-living and epibiotic bacterial activity by copepod excretions. FEMS Microbiol Ecol 14:255-262

- Carman KR, Dobbs FC (1997) Epibiotic microorganisms on copepods and other marine crustaceans. Microsc Res Tech 37:116-135

Caron DA, Madin LP, Cole JJ (1989) Composition and degradation of salp fecal pellets: implications for vertical flux in oceanic environments. J Mar Res 47:829-850

Carrias JF, Sime-Ngando T (2009) Bacteria, attached to surfaces. In: Likens GE (ed) Encyclopedia of inland waters, Vol 3. Elsevier, Oxford, p 182-192

> Cauchie HM (2002) Chitin production by arthropods in the hydrosphere. Hydrobiologia 470:63-96

Cherry RD, Higgo JJW, Fowler SW (1978) Zooplankton fecal pellets and element residence times in the ocean. Nature 274:246-248

> Colwell RR (1996) Global climate and infectious disease: the cholera paradigm. Science 274:2025-2031

Costello JH, Colin SP, Dabiri JO (2008) Medusan morphospace: phylogentic constraints, biomechanical solutions, and ecological consequences. Invertebr Biol 127:265-290

Cottingham KL, Chiavelli DA, Taylor RK (2003) Environmental microbe and human pathogen: the ecology and microbiology of Vibrio cholerae. Front Ecol Environ 1:80-86

Cottrell MT, Kirchman DL (2003) Contribution of major bacterial groups to bacterial biomass production (thymidine and leucine incorporation) in the Delaware Estuary. Limnol Oceanogr 48:168-178

Dabiri JO, Colin SP, Costello JH, Gharib M (2005) Flow patterns generated by oblate medusan jellyfish: field measurements and laboratory analyses. J Exp Biol 208: $1257-1265$

Dam HG, Peterson WT (1988) The effect of temperature on the gut clearance rate constant of planktonic copepods. J Exp Mar Biol Ecol 123:1-14

Dattagupta S, Schaperdoth I, Montanari A, Mariani S, Kita N, Valley JW, Macalady JL (2009) A novel symbiosis between chemoautotrophic bacteria and a freshwater cave amphipod. ISME J 3:935-943

de Angelis M, Lee C (1994) Methane production during zooplankton grazing on marine phytoplankton. Limnol Oceanogr 39:1298-1308

Delille D, Razouls S (1994) Community structures of heterotrophic bacteria of copepod fecal pellets. J Plankton Res 16:603-615

Diaz MR, Visscher PT, Taylor BF (1992) Metabolism of dimethylsulfoniopropionate and glycine betaine by a marine bacterium. FEMS Microbiol Lett 96:61-66

> Ducklow HW (1999) The bacterial component of the oceanic euphotic zone. FEMS Microbiol Ecol 30:1-10

> Dunne WM Jr (2002) Bacteria adhesion: Seen any good biofilms lately? Clin Microbiol Rev 15:155-166

> Eilers H, Pernthaler J, Glöckner FO, Amann R (2000) Culturability and in situ abundance of pelagic bacteria from the North Sea. Appl Environ Microbiol 66:3044-3051

Elliott DT, Tang KW (2009) Simple staining method for differentiating live and dead marine zooplankton in field samples. Limnol Oceanogr Methods 7:585-594

Flintoft L (2004) Bacterial physiology: unlocking chitin degradation. Nat Rev Microbiol 2:90

Flood PR (1991) Architecture of and and water circulation and flow rate in the house of the planktonic tunicate Oikopleura labradoriensis. Mar Biol 111:95-111
Folt CL, Burns CW (1999) Biological drivers of zooplankton patchiness. Trends Ecol Evol 14:300-305

Fong W, Mann KH (1980) Role of gut flora in the transfer of amino acids through a marine food chain. Can J Fish Aquat Sci 37:88-96

> Friedland KD, Ahrenholz DW, Haas LW (2005) Viable gut passage of cyanobacteria through the filter-feeding fish Atlantic menhaden, Brevoortia tyrannus. J Plankton Res 27:715-718

Gardner WD (1977) Incomplete extraction of rapidly settling particles from water samples. Limnol Oceanogr 22: 764-768

Gooday GW (1990) The ecology of chitin degradation. Adv Microb Ecol 11:387-430

> Gowing MM, Silver MW (1983) Origins and microenvironments of bacteria mediating fecal pellet decomposition in the sea. Mar Biol 73:7-16

Gram L, Grossart HP, Schlingloff A, Kiørboe T (2002) Possible quorum sensing in marine snow bacteria: production of acylated homoserine lactones by Roseobacter strains isolated from marine snow. Appl Environ Microbiol 68: 4111-4116

Gries T, Güde H (1999) Estimates of the nonconsumptive mortality of mesozooplankton by measurement of sedimentation losses. Limnol Oceanogr 44:459-465

Grossart HP (2010) Ecological consequences of bacterioplankton lifestyles: changes in concepts are needed. Environ Microbiol, doi:10.1111/j.1758-2229.2010.00179.x

> Grossart HP, Simon M (1998) Bacterial colonization and microbial decomposition of limnetic organic aggregates (lake snow). Aquat Microb Ecol 15:127-140

Grossart HP, Simon M, Logan BE (1997) Formation of macroscopic organic aggregates (lake snow) in a large lake: the significance of transparent exopolymer particles, phytoplankton, and zooplankton. Limnol Oceanogr 42: 1651-1659

> Grossart HP, Dziallas C, Tang KW (2009) Bacterial diversity associated with freshwater zooplankton. Environ Microbiol Rep 1:50-55

Grossart HP, Dziallas C, Leunert F, Tang KW (2010) Bacteria dispersal by hitchhiking on zooplankton. Proc Natl Acad Sci USA, doi:10.1073/pnas.1000668107

Hansen B, Bech G (1996) Bacteria associated with a marine planktonic copepod in culture. I. Bacterial genera in seawater, body surface, intestines and fecal pellets and succession during fecal pellet degradation. J Plankton Res 18:257-273

Hansson LJ, Norrman B (1995) Release of dissolved organic carbon (DOC) by the scyphozoan jellyfish Aurelia aurita and its potential influence on the production of planktic bacteria. Mar Biol 121:527-532

Harding GCH (1973) Decomposition of marine copepods. Limnol Oceanogr 18:670-673

Harris JM (1993) The presence, nature, and role of gut microflora in aquatic invertebrates: a synthesis. Microb Ecol 25:195-231

> Heidelberg JF, Heidelberg KB, Colwell RR (2002) Bacteria of the ?-subclass Proteobacteria associated with zooplankton in Chesapeake Bay. Appl Environ Microbiol 68:5498-5507

> Holland R, Hergenrader R (1981) Bacterial epibionts of diaptomid copepods. Trans Am Microsc Soc 100:56-65

Honjo S, Roman MR (1978) Marine copepod fecal pellets: production, preservation, and sedimentation. J Mar Res 36: $45-57$

> Hülsmann S, Voigt H (2002) Life history of Daphnia galeata in a hypertrophic reservoir and consequences of non-consumptive mortality for the initiation of a midsummer decline. Freshw Biol 47:2313-2324 
Hülsmann S, Weiler W (2000) Adult, not juvenile mortality as a major reason for the midsummer decline of a Daphnia population. J Plankton Res 22:151-068

Huq A, Small EB, West PA, Huq MI, Rahman R, Colwell RR (1983) Ecological relationships between Vibrio cholerae and planktonic crustacean copepods. Appl Environ Microbiol 45:275-283

Itoi S, Okamura T, Koyama Y, Sugita H (2006) Chitinolytic bacteria in the intestinal tract of Japanese coastal fishes. Can J Microbiol 52:1158-1163

Jacobsen T, Azam F (1984) Role of bacteria in copepod fecal pellet decomposition: colonization, growth rates and mineralization. Bull Mar Sci 35:495-502

> Jerde CW, Lasker R (1966) Moulting of euphausiid shrimp: shipboard observation. Limnol Oceanogr 11:120-124

Jeuniaux C (1971) Hemolymph-Arthropoda. In: Florkin M, Scheer BT (eds) Chemical zoology, Vol VI. Academic Press, New York, NY, p 63-118

Jeuniaux C (1982) La chitine dans le regne animal. Bull Soc Zool Fr 107:363-386

Keller MD, Korjeff-Bellows W (1996) Physiological aspects of the production of dimethylsulfoniopropionate (DMSP) by marine phytoplankton. In: Kiene RP, Visscher PT, Keller MD, Kirst GO (eds) Biological and environmental chemistry of DMSP and related sulfonium compounds. Plenum Press, New York, NY, p 131-142

Keyhani NO, Roseman S (1999) Physiological aspects of chitin catabolism in marine bacteria. Biochim Biophys Acta 1473: 108-122

King CH, Sanders RW, Shotts EB Jr, Porter KG (1991) Differential survival of bacteria ingested by zooplankton from a stratified eutrophic lake. Limnol Oceanogr 36:829-845

Kiørboe T, Grossart HP, Ploug H, Tang K (2002) Mechanisms and rates of bacterial colonization of sinking aggregates. Appl Environ Microbiol 68:3996-4006

Kirchman DL, White J (1999) Hydrolysis and mineralization of chitin in the Delaware Estuary. Aquat Microb Ecol 18: 187-196

Kirchner M (1995) Microbial colonization of copepod body surfaces and chitin degradation in the sea. Helgol Meeresunters 49:201-212

Kirn TJ, Jude BA, Taylor RK (2005) A colonization factor links Vibrio cholerae environmental survival and human infection. Nature 438:863-866

Kobari T, Ikeda T (2001) Ontogenetic vertical migration and life cycle of Neocalanus plumchrus (Crustacea: Copepoda) in the Oyashio region, with notes on regional variations in body sizes. J Plankton Res 23:287-302

Komar PD, Morse AP, Small LF (1981) An analysis of sinking rates of natural copepod and euphausiid fecal pellets. Limnol Oceanogr 26:172-180

Koropatnick TA, Engle JT, Apicella MA, Stabb EV, Goldman WE, McFall-Ngai MJ (2004) Microbial factor-mediated development in a host-bacterial mutualism. Science 306: 1186-1188

Kragh T, Sondergaard M, Borch NH (2006) The effect of zooplankton on the dynamics and molecular composition of carbohydrates during an experimental algal bloom. J Limnol 65:52-58

> Lampert W (1989) The adaptive significance of diel vertical migration of zooplankton. Funct Ecol 3:21-27

> Lampitt RS, Noji T, von Bodungen B (1990) What happens to zooplankton faecal pellets? Implications for material flux. Mar Biol 104:15-23

Lawrence JR, Caldwell DE (1987) Behavior of bacterial stream populations within the hydrodynamic boundary layers of surface microenvironments. Microb Ecol 14: 15-27
Lebrato M, Jones DOB (2009) Mass deposition event of Pyrosoma atlanticum carcasses off Ivory Coast (West Africa). Limnol Oceanogr 54:1197-1209

Ledyard KM, Dacey JWH (1996) Microbial cycling of DMSP and DMS in coastal and oligotrophic seawater. Limnol Oceanogr 41:33-40

Marty DG (1993) Methanogenic bacteria in seawater. Limnol Oceanogr 38:452-456

Meibom KL, Li XB, Nielsen AT, Wu CY, Roseman S, Schoolnik GK (2004) The Vibrio cholera chitin utilization program. Proc Natl Acad Sci USA 101:2524-2529

Michotey V, Bonin P (1997) Evidence for anaerobic bacterial processes in the water column: denitrification and dissimilatory nitrate ammonification in the northwestern Mediterranean Sea. Mar Ecol Prog Ser 160:47-56

Mills CE (2001) Jellyfish blooms: Are populations increasing globally in response to changing ocean conditions? Hydrobiologia 451:55-68

Møller EF (2005) Sloppy feeding in marine copepods: preysize-dependent production of dissolved organic carbon. J Plankton Res 17:27-35

Møller EF, Thor P, Nielsen TG (2003) Production of DOC by Calanus finmarchicus, C. glacialis and C. hyperboreus through sloppy feeding and leakage from fecal pellets. Mar Ecol Prog Ser 262:185-191

Møller EF, Riemann L, Søndergaard M (2007) Bacteria associated with copepods: abundance, activity and community composition. Aquat Microb Ecol 47:99-106

> Nagasawa S, Nemoto T (1988) Presence of bacteria in guts of marine crustaceans and on their fecal pellets. J Plankton Res 10:559-564

> Olsen AI, Olsen Y, Attarmadal Y, Chrisie K, Birkbeck TH, Skjermo J, Vadstein O (2000) Effects of short term feeding of microalgae on the bacterial flora associated with juvenile Artemia franciscana. Aquaculture 190:11-25

> Oremland RS (1979) Methanogenic activity in plankton samples and fish intestines: a mechanism for in situ methanogenesis in oceanic surface waters. Limnol Oceanogr 24:1136-1141

Parsons TR, Takahashi M, Hargrave B (1977) Biological oceanographic processes, 2nd edn. Pergamon Press, Oxford

Pathak SP, Gopal K (2005) Occurrence of antibiotic and metal resistance in bacteria from organs of river fish. Environ Res 98:100-103

Peduzzi P, Herndl GJ (1992) Zooplankton activity fueling the microbial loop: differential growth response of bacteria from oligotrophic and eutrophic waters. Limnol Oceanogr 37:1087-1092

Peter H, Sommaruga R (2008) An evaluation of methods to study the gut bacterial community composition of freshwater zooplankton. J Plankton Res 30:997-1006

Pitt KA, Welsh DT, Condon RH (2009) Influence of jellyfish blooms on carbon, nitrogen and phosphorus cycling and plankton production. Hydrobiologia 616:133-149

Plante CJ, Shriver AG (1998) Patterns of differential digestion of bacteria in deposit feeders: a test of resource partitioning. Mar Ecol Prog Ser 163:253-258

Plante CJ, Wilde SB (2001) Bacterial recolonization of depositfeeder egesta: in situ regrowth or immigration? Limnol Oceanogr 46:1171-1181

Pond DW, Harris RP, Brownlee C (1995) A microinjection technique using a $\mathrm{pH}$-sensitive dye to determine the gut pH of Calanus helgolandicus. Mar Biol 123:75-79

Poulicek M, Gaill F, Goffinet G (1998) Chitin biodegradation in marine environments. ACS Symp Ser 707:163-210 
Proctor LM (1997) Nitrogen-fixing, photosynthetic, anaerobic bacteria associated with pelagic copepods. Aquat Microb Ecol 12:105-113

Pruzzo C, Crippa A, Bertone S, Pane L, Carli A (1996) Attachment of Vibrio alginolyticus to chitin mediated by chitinbinding proteins. Microbiology 142:2181-2186

Pruzzo C, Vezzulli L, Colwell RR (2008) Global impact of Vibrio cholerae interactions with chitin. Environ Microbiol 10:1400-1410

Purcell JE, Uye S, Lo WT (2007) Anthropogenic causes of jellyfish blooms and their direct consequences for humans: a review. Mar Ecol Prog Ser 350:153-174

Ramaiah N, Hill RT, Chun J, Ravel J, Matte MH, Straube WL, Colwell RR (2000) Use of a chiA probe for detection of chitinase genes in bacteria from the Chesapeake Bay. FEMS Microbiol Ecol 34:63-71

Rico-Mora R, Voltolina D (1995) Effects of bacterial isolates from Skeletonema costatus cultures on the survival of Artemia franciscana nauplii. J Invertebr Pathol 66: 203-204

Riemann L, Azam F (2002) Widespread N-acetyl-D-glucosamine uptake among pelagic marine bacteria and its ecological implications. Appl Environ Microbiol 68: 5554-5562

Riemann L, Titelman J, Båmstedt U (2006) Links between jellyfish and microbes in a jellyfish dominated fjord. Mar Ecol Prog Ser 325:29-42

Schuett C, Doepke H (2009) Endobiotic bacteria and their pathogenic potential in cnidarian tentacles. Helgol Mar Res, doi 10.1007/s10152-009-0179-2

Selmi G (2001) Ectosymbiotic bacteria on ciliated cells of a rotifer. Tissue Cell 33:258-261

Simon M, Grossart HP, Schweitzer B, Ploug H (2002) Microbial ecology of organic aggregates in aquatic ecosystems. Aquat Microb Ecol 28:175-211

Sochard MR, Wilson DF, Austin B, Colwell RR (1979) Bacteria associated with the surface and gut of marine copepods. Appl Environ Microbiol 37:750-759

Stief P, Poulsen M, Nielsen LP, Brix H, Schramm A (2009) Nitrous oxide emission by aquatic macrofauna. Proc Natl Acad Sci USA 106:4296-4300

Tamplin ML, Gauzens AL, Huq A, Sack D, Colwell RR (1990) Attachment of Vibrio cholera serogroup O1 to zooplankton and phytoplankton of Bangladesh waters. Appl Environ Microbiol 56:1977-1980

Tang KW (2005) Copepods as microbial hotspots in the ocean: effects of host feeding activities on attached bacteria. Aquat Microb Ecol 38:31-40

Tang KW, Dam HG, Visscher PT, Fenn TD (1999) Dimethylsulfoniopropionate (DMSP) in marine copepods and its relation with diets and salinity. Mar Ecol Prog Ser 179: 71-79

Tang KW, Visscher PT, Dam HG (2001) DMSP-consuming bacteria associated with the calanoid copepod Acartia tonsa (Dana). J Exp Mar Biol Ecol 256:185-198

Tang KW, Freund CS, Schweitzer CL (2006a) Occurrence of copepod carcasses in the lower Chesapeake Bay and their decomposition by ambient microbes. Estuar Coast Shelf Sci 68:499-508

Tang KW, Hutalle KML, Grossart HP (2006b) Microbial abundance, composition and enzymatic activity during decomposition of copepod carcasses. Aquat Microb Ecol 45: $219-227$
Tang KW, Bickel SL, Dziallas C, Grossart HP (2009a) Microbial activities accompanying decomposition of cladoceran and copepod carcasses under different environmental conditions. Aquat Microb Ecol 57:89-100

Tang K, Dziallas C, Hutalle-Schmelzer K, Grossart HP (2009b) Effects of food on bacterial community composition associated with the copepod Acartia tonsa Dana. Biol Lett 5:549-553

> Thor P, Dam HG, Rogers DR (2003) Fate of organic carbon released from decomposing copepod fecal pellets in relation to bacterial production and ectoenzyme activity. Aquat Microb Ecol 33:279-288

Tilly K, Elias AF, Errett J, Fischer E, Iyer R, Schwartz I, Bono JL, Rosa P (2001) Genetics and regulation of chitobiose utilization in Borrelia burgdorferi. J Bacteriol 183: $5544-5553$

Tinta T, Malej A, Kos M, Turk V (2010) Degradation of the Adriatic medusa Aurelia sp. by ambient bacteria. Hydrobiologia 645:179-191

> Titelman J, Riemann L, Sørnes TA, Nilsen T, Griekspoor P, Båmstedt U (2006) Turnover of dead jellyfish: stimulation and retardation of microbial activity. Mar Ecol Prog Ser 325:43-58

Turley CM, Mackie PJ (1995) Bacteria and cyanobacterial flux to the deep NE Atlantic on sedimenting particles. DeepSea Res I 42:1453-1474

Turner JT (1979) Microbial attachment to copepod fecal pellets and its possible significance. Trans Am Microsc Soc 98:131-135

Uye S (1985) Resting egg production as a life history strategy of marine planktonic copepods. Bull Mar Sci 37:440-449

Verschuere L, Rombaut G, Huys G, Dhont J, Sorgeloos P, Verstraet W (1999) Microbial control of the culture of Artemia juveniles through preemptive colonization by selected bacterial strains. Appl Environ Microbiol 65:2527-2533

> Verschuere L, Heang H, Criel G, Sorgeloos P, Verstraete W (2000) Selected bacterial strains protect Artemia spp. from the pathogenic effects of Vibrio proteolyticus CW8T2. Appl Environ Microbiol 66:1139-1146

> Visscher PT, Diaz MR, Taylor BF (1992) Enumeration of bacteria which cleave or demethylate dimethylsulfoniopropionate in the Caribbean Sea. Mar Ecol Prog Ser 89:293-296

> Visser AW, Jónasdóttir SH (1999) Lipids, buoyancy and the seasonal vertical migration of Calanus finmarchicus. Fish Oceanogr 8:100-106

> Wainwright PF, Mann KH (1982) Effect of antimicrobial substances on the ability of the mysid shrimp Mysis stenolepis to digest cellulose. Mar Ecol Prog Ser 7:309-313

Weiss P, Schweitzer B, Amann R, Simon M (1996) Identification in situ and dynamics of bacteria on limnetic organic aggregates (lake snow). Appl Environ Microbiol 62: 1998-2005

> West EJ, Welsh DT, Pitt KA (2009) Influence of decomposing jellyfish on the sediment oxygen demand and nutrient dynamics. Hydrobiologia 616:151-160

Wurzbacher C, Bärlocher F, Grossart HP (2010) Fungi in lake ecosystems. Aquat Microb Ecol 59:125-149

Yu C, Lee AM, Bassler BL, Roseman S (1991) Chitin utilization by marine bacteria - a physiological function for bacterial adhesion to immobilized carbohydrates. J Biol Chem 266: 24260-24267 